Original Article

\title{
Water quality assessment of the Demetrio stream: an affluent of the Gravataí River in the South of Brazil
}

\author{
Qualidade da água do arroio Demetrio: um afluente do rio Gravataí no sul do Brasil

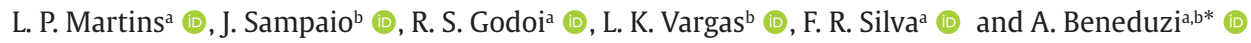 \\ ${ }^{a}$ Universidade La Salle - Unilasalle, Canoas, RS, Brasil

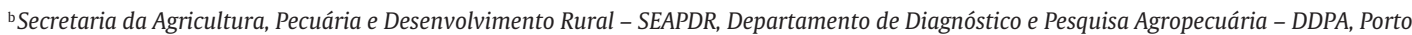 \\ Alegre, RS, Brasil
}

\begin{abstract}
The Gravataí River basin, one of the main water sources of the metropolitan region of Porto Alegre, is among the ten most polluted rivers in Brazil. Water quality is monitored only through physico-chemical and microbiological parameters in Brazil, and in this context, considering the importance of the use of biomarkers in complementing the analysis of water, the present study aimed to evaluate the environmental quality of the main affluent of the Gravataí River, Demetrio stream, through physico-chemical, microbiological, and cytogenotoxic criteria, at the stream source (P1), whereas samples P2 and P3 were obtained from the upstream near the area with the highest urban density and the downstream near the meeting point with the Gravataí River, respectively. The results for copper concentration and color classified the Demetrio stream as Class 4 in general, that is, the water is suitable only for navigation and to landscape harmony. The main genotoxic alterations (micronuclei and nuclear buds) were observed in P2, in which were obtained the highest levels of copper, in addition to iron and manganese. Anthropic interventions were observed in P1 and P2; however, due to its low metal concentration, P3, near the Gravataí River, manifested an improvement in environmental quality.
\end{abstract}

Keywords: environmental monitoring, cytogenotoxicity, Allium cepa, CONAMA resolution ํo 357/2005.

\begin{abstract}
Resumo
A bacia do rio Gravataí, uma das principais fontes de água da região metropolitana de Porto Alegre, está entre os dez rios mais poluídos do Brasil. No Brasil a qualidade da água é monitorada apenas através de parâmetros físico-químicos e microbiológicos e, nesse contexto, considerando a importância do uso de biomarcadores para complementar a análise da água, o presente estudo teve como objetivo avaliar a qualidade ambiental do principal afluente do Rio Gravataí, o arroio Demétrio, através de critérios físico-químicos, microbiológicos e citogenotóxicos, na nascente do arroio (P1), a montante e próximo à área com maior densidade urbana (P2) e a jusante e próximo ao ponto de encontro com o rio Gravataí (P3). Os resultados para a cor da água e para a concentração de cobre classificaram o arroio Demétrio como Classe 4 em geral, ou seja, esta água é adequada apenas para navegação e harmonia da paisagem. As principais alterações genotóxicas (micronúcleos e brotos nucleares) foram observadas no P2, no qual foram obtidos os maiores teores de cobre, além de ferro e manganês. Intervenções antrópicas foram observadas em P1 e P2; no entanto, devido à sua baixa concentração de metais, o P3, próximo ao rio Gravataí, manifestou uma melhoria na qualidade ambiental.
\end{abstract}

Palavras-chave: monitoramento ambiental, citogenotoxicidade, Allium cepa, resolução CONAMA nº 357/2005.

\section{Introduction}

In recent years, human activities have posed serious threats to water resources (Kaliberda et al., 2008). The quality of water for domestic supply is affected by pollution caused by different sources, such as domestic, industrial, urban, and agricultural effluents (Merten and Minella, 2002). The release of sanitary sewage into water bodies severely affects fauna, flora, and humans (Carvalho and Orsine, 2011). According to the National Sanitation Information System - SNIS (Brasil, 2015),

although the treatment rate increased by $11 \%$ between 2005 and 2015 , only $42.7 \%$ of all Brazilian sanitary sewage is treated, and in some regions the rate is still less than $10 \%$. The average rate of sewage collection ranged from $20 \%$ to $40 \%$ in the State of Rio Grande do Sul (RS), Brazil (Brasil, 2016).

In Brazil, polluted rivers water when monitored, its quality can be determined according to the standards established in the Resolution of the National Environmental

*e-mail: anebeneduzi@gmail.com

Received: March 3, 2020 - Accepted: August 27, 2020

This is an Open Access article distributed under the terms of the Creative Commons Attribution License, which permits unrestricted use, distribution, and reproduction in any medium, provided the original work is properly cited. 
Council (CONAMA) no 357 (Brasil, 2005). This "water quality" does not refer to the state of purity, it denotes the physicochemical characteristics of water (Merten and Minella, 2002). According to Sperling (2005), water quality of a region is determined by its natural conditions as well as by the use of soil in the river basin. However, the most proper way to understand the health of the ecosystem is to biomonitor the environment because physicochemical measures of water quality can determine contamination sources, but they do not evaluate at biological responses to pollution. One biological monitor that has been an important tool for environmental monitoring studies is the Allium cepa. The A. cepa test has been used to detect a great variety of environmental pollutants as heavy metals, pesticides, aromatic hydrocarbons, textile dyes, complex mixtures, and the results obtained have been satisfactory in the different studies (Leme and Marin-Morales, 2009; Dalzochio et al., 2016).

Gravataí River is among the ten most polluted rivers in Brazil (Pessoa, 2017), and is located in the metropolitan region of Porto Alegre (RS, Brazil) with an area of approximately $2.020 \mathrm{~km}^{2}$, providing public water supply to about 500.000 inhabitants in five municipalities (Salomoni et al., 2011). Demetrio stream is one of the main affluent of the Gravataí River basin, covering $12.51 \%$ of the total area (Volpi and Jungblut, 1994). Throughout its course, the Demetrio stream runs through rural and urban areas, flowing directly into the river Gravataí, on its right bank (Quevedo et al., 2017). The hydrographical basin of Gravataí river has a relevant social, economic, and cultural importance. The industrial cluster has grown considerably over the past years as has the urban population as well and this generated an increase of pollutants dumped in the river, as a result of farming irrigation, water supply for animals, industrial and domestic sewage, solid residue, urban draining, rural diffusing sources, and atmospheric pollutants precipitation (Salomoni et al., 2011).

In this context, considering the interest to assess the impact of pollutants dispersed in water, as well as the importance of the use of biomarkers to complement the water physicochemical analysis, this study aims to evaluate the environmental quality of the Demetrio stream water, main affluent of Gravataí River, through physical-chemical, microbiological and cytogenotoxic criteria.

\section{Materials and Methods}

\subsection{Demetrio stream water samples}

Water samples were collected in December/2016, and all sample points were defined according to their geographical characteristics (Figure 1). Sample point 1 (P1) was collected from near the source (latitude -29.77029 and longitude -50.872087), whereas samples 2 (P2) and 3 (P3) were obtained from the upstream near the area with the highest urban density (latitude -29.919287 and longitude -50.935974) and from the downstream near the meeting point of the Demetrio stream with the Gravataí River (latitude -29.945642 and longitude -50.981018).

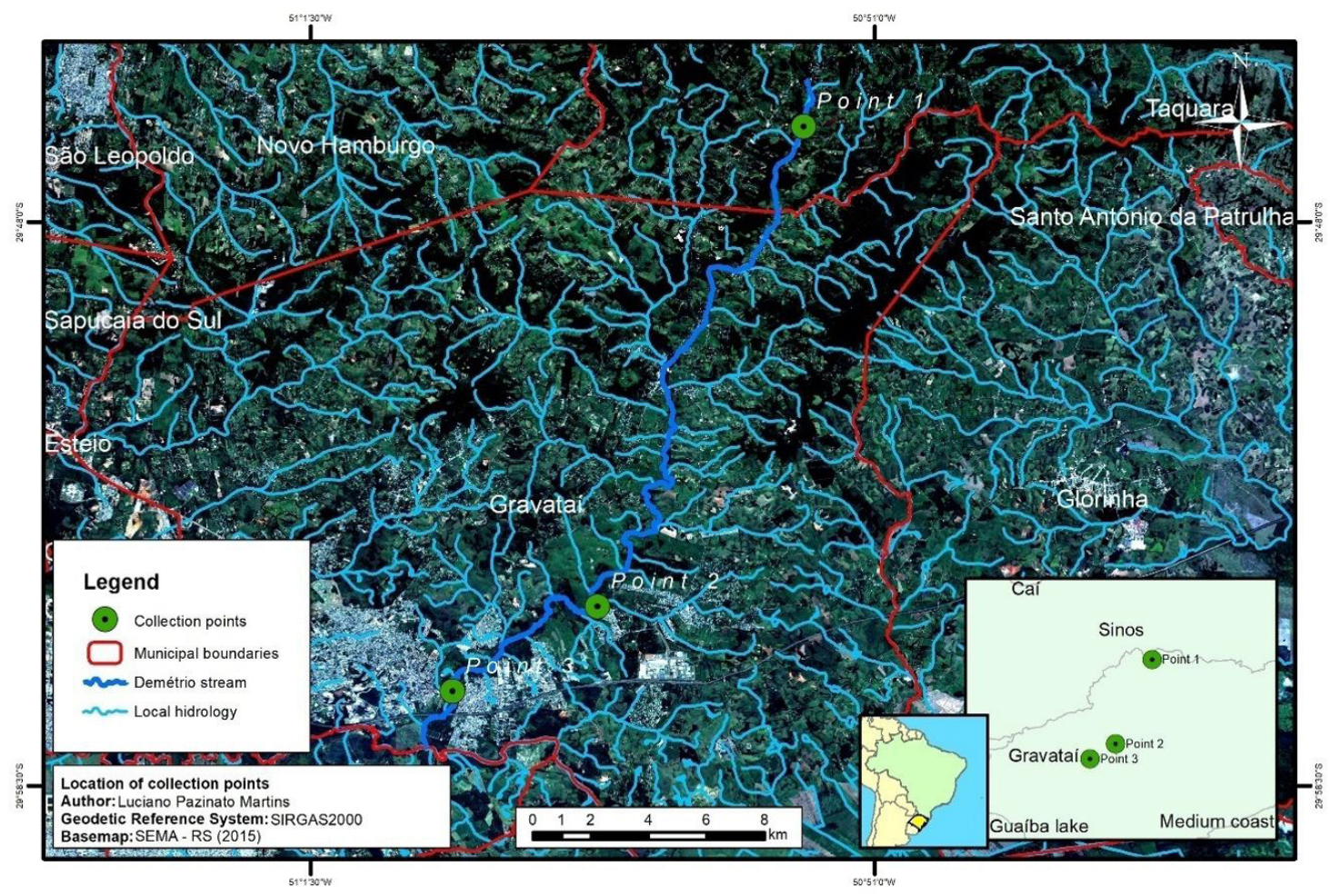

Figure 1. Satellite view of the area and water sampling points of Demétrio stream: point 1 source, point 2 and point 3 , upstream near the area with the highest urban density and from the downstream near the meeting point of the Demétrio stream with the Gravataí River. 
The collected water samples were stored in 1,000 mL and $500 \mathrm{~mL}$ sterilized glass vials: (1) glass vials were first submerged in waters of the sample sites for a water wash of the point to be collected, (2) glass vials were again submerged in waters of the respective sample points and immediately sealed and refrigerated at $4 \pm 2{ }^{\circ} \mathrm{C}$ to protect from light.

\subsection{Physicochemical and microbiological analysis}

The collected water samples were sent to the Laboratory of Environmental Studies and Nanotechnology Development of the University La Salle (Canoas/RS) and analyzed for the physicochemical parameters: chloride, fluoride, nitrate, sulfate, turbidity, and color (APHA, 2005). Temperatures and $\mathrm{pH}$ values of the samples were measured at the time of collection (HI 8424 pH/ORP meter- Hanna Instruments). The identification and quantification of dissolved aluminum ( $\mathrm{Al})$, cadmium (Cd), lead (Pb), cobalt (Co), dissolved copper $(\mathrm{Cu})$, total chromium $(\mathrm{Cr})$, dissolved iron (Fe), manganese $(\mathrm{Mn})$, mercury $(\mathrm{Hg})$, nickel (Ni), and zinc $(\mathrm{Zn})$ were performed in the Green Lab Laboratory (Porto Alegre/RS). The adopted analytical method was based in Standard Methods for the Examination of Water and Wastewater (APHA, 2005) and detection limits (mg/L) for $\mathrm{Al}, \mathrm{Cu}, \mathrm{Fe}$ and $\mathrm{Zn}$ : 0.006, Cd: 0.0006, Pb: 0.004, Co: 0.001, total Cr: 0.003, Mn and Ni: 0.001 and Hg: 0.0002 .

From each sample, serial dilutions were made up to the order of $10^{-5}$ dilution. For the quantification of total and thermotolerant coliforms, the Most Probable Number (MPN) technique was used, and the dilutions were inoculated on a chromogenic substrate Colilert (Idexx) in five sets of five tubes and then incubated for $24 \mathrm{~h}$ at $35^{\circ} \mathrm{C}$. The tubes that changed their colors to yellow were considered as positive for total coliforms. Further, the positive tubes were submitted to ultraviolet light, and the tubes with the emission of fluorescence were considered as positive for thermotolerant coliforms (Edberg et al., 1988).

\subsection{Allium cepa test}

All assays were carried out only with one kind of $A$. серa seed (variety Baia Periforme; Isla ${ }^{\circledR}$ Sementes) to avoid different responses in different stages of the process (Caritá and Marin-Morales, 2008). A. cepa seeds were exposed to water samples in a Petri dish for each sample point. The control tests were carried out with distilled water (for negative control) and copper sulfate $(0.0002 \mathrm{~g} / \mathrm{L}$ ) (for positive control) (Carvalho et al., 2011). After five days of exposure, seed roots were immediately immersed in acetic acid and ethanol ( $1: 3 ; \mathrm{v} / \mathrm{v})$ for $24 \mathrm{~h}$. Root meristems were washed with distilled water and hydrolyzed in $1 \mathrm{~N}$ $\mathrm{HCl}$ at $60{ }^{\circ} \mathrm{C}$ for $10 \mathrm{~min}$, then washed in distilled water again, dried in filter paper, and finally, exposed to Schiff's reagent in the dark for $15 \mathrm{~min}$ (Mello and Vidal, 1978). After staining, root meristems were rinsed with distilled water until the complete removal of reagents. Slides were first prepared from the squashing of root meristems with one drop of $45 \%$ acetic acid (Fiskesjo, 1993), then frozen at $-20{ }^{\circ} \mathrm{C}$, and finally, fixed with $70 \%$ ethanol by removing the coverslip. The prepared slides were contra stained in a fast-green solution for $2 \mathrm{~s}$ and then dried at room temperature overnight (Matsumoto et al., 2006). The contra-stained slides were mounted in synthetic resin for further analysis. According to Leme and Marin-Morales (2008), for each treatment were analyzed by counting 5000 cells, being 500 cells per slide, comprising a total of 10 slides, and then the value of mitotic index (MI) [(number of dividing cells/total number of observed cells) $\times 100$ ] was estimated. Similarly, nuclear alterations due to micronucleus, nuclear buds, and other chromosomal alterations (sum of interphase, anaphase, and telophase with nucleoplasmatic bridge, micronucleus in telophase, anaphase, and metaphase with a chromosomal loss) were also identified and measured. In addition, toxicity was evaluated based on seed germination index (GI) [the ratio of the number of germinated seeds to the total number of seeds allowed to germinate].

\subsection{Statistical analysis}

Data normality was assessed by the KolmogorovSmirnov test. The cytogenotoxic variables were measured by the Kruskal-Wallis test associated with Dunn's test and indicated a non-parametric distribution. The p-values $<0.05$ were considered significant. All statistical analyses were performed using GraphPad Prism version 5.0. For correlation analysis, the Microsoft Excel RQUAD function was used. For the integrated analysis of physicochemical and microbiological parameters, Principal Component Analysis (PCA) was performed in Past 3.14 software.

\section{Results}

\subsection{Physicochemical and microbiological analysis}

For most of the physicochemical parameters analyzed (Table 1), such as cadmium, lead, chloride, cobalt, total chromium, fluoride, mercury, nickel, nitrate, sulfate, zinc, turbidity, and $\mathrm{pH}$, the water samples were classified within Class 1 , according to the criteria established by CONAMA Resolution no 357 (Brasil, 2005), i.e., water destined to be supplied for human consumption post simple treatment, for protection of aquatic communities, and irrigation of raw vegetable crops. All samples, based on their color patterns, were classified as Class 4 (Brasil, 2005) that is, waters that can only be used for navigation and landscape harmony. Iron concentrations in all samples were classified as Class 3 of water intended for human consumption, after conventional or advanced treatment, to the irrigation of arboreal, cereal and forage crops, and amateur fishing. P3 had the highest iron (Fe) concentration of $0.495 \mathrm{mg} / \mathrm{L}$, whereas the lowest value was obtained for P1 $(0.137 \mathrm{mg} / \mathrm{L})$. According to the physicochemical pattern of copper $(\mathrm{Cu})$, P1, P2, and P3 were classified as Class $1(<0.006 \mathrm{mg} / \mathrm{L})$, Class 4 (0.021 mg/L), and Class 3 (0.012 mg/L), respectively. Moreover, manganese ( $\mathrm{Mn}$ ) was also a metal that was classified according to their concentrations, samples P2 (0.172 mg/L) and P3 (0.146 mg/L) were classified as Class 3 (Brasil, 2005). In addition, aluminum (Al) was only found in P3 (Class 3). 
Table 1. Physicochemical parameters of the sampled points of the Demétrio stream: point 1 (P1), point 2 (P2) and point 3 (P3).

\begin{tabular}{|c|c|c|c|c|}
\hline Parameters & P1 & P2 & P3 & $\begin{array}{c}\text { Standard (Class 1) CONAMA no } \\
357 \text { (Brasil, 2005) }\end{array}$ \\
\hline Aluminum (mg/L) & $<0.006^{*}$ & $0.089^{*}$ & $0.127 \#$ & $<0.1$ \\
\hline Cadmium (mg/L) & $<0.0006^{*}$ & $<0.0006^{*}$ & $<0.0006^{*}$ & $<0,001$ \\
\hline Lead $(\mathrm{mg} / \mathrm{L})$ & $<0.004^{*}$ & $<0.004^{*}$ & $<0.004^{*}$ & $<0,01$ \\
\hline Chloride $(\mathrm{mg} / \mathrm{L})$ & $4.938^{*}$ & $7.977^{*}$ & $6.837^{*}$ & $<250$ \\
\hline Cobalt (mg/L) & $<0.001^{*}$ & $<0.001^{*}$ & $<0.001^{*}$ & $<0,05$ \\
\hline Copper (mg/L) & $<0.006^{*}$ & $0.021 \dagger$ & $0.012 \#$ & $<0,009$ \\
\hline Total Chromium (mg/L) & $<0.003^{*}$ & $<0.003^{*}$ & $<0.003^{*}$ & $<0,05$ \\
\hline $\operatorname{Iron}(\mathrm{mg} / \mathrm{L})$ & $0.137 \#$ & $0.445 \#$ & $0.495 \#$ & $<0.3$ \\
\hline Fluoride (mg/L) & $0.086^{*}$ & $0.118^{*}$ & $0.125^{*}$ & $<1.4$ \\
\hline Manganese (mg/L) & $0.052^{*}$ & $0.172 \#$ & $0.146 \#$ & $<0.1$ \\
\hline Mercury (mg/L) & $<0.0002^{*}$ & $<0.0002^{*}$ & $<0.0002^{*}$ & $<0.0002$ \\
\hline Nickel (mg/L) & $<0.001^{*}$ & $<0.001^{*}$ & $<0.001^{*}$ & $<0,025$ \\
\hline Nitrate $(\mathrm{mg} / \mathrm{L})$ & $2.433^{*}$ & $2.142^{*}$ & $3.186^{*}$ & $<10,0$ \\
\hline Sulfate (mg/L) & $1.868^{*}$ & $3.455^{*}$ & $3.041^{*}$ & $<250$ \\
\hline $\operatorname{Zinc}(\mathrm{mg} / \mathrm{L})$ & $<0.006^{*}$ & $<0.006^{*}$ & $<0.006^{*}$ & $<0,18$ \\
\hline Turbidity (UNT) & $3.35^{*}$ & $6.14^{*}$ & $7.48^{*}$ & $<40$ \\
\hline Color (MG Pt/L) & $92.35 \dagger$ & $178.61 \dagger$ & $188.39 \dagger$ & 0 \\
\hline $\mathrm{pH}$ & $6.5^{*}$ & $6.7^{*}$ & $6.8^{*}$ & $6,0-9,0$ \\
\hline Temperature $\left({ }^{\circ} \mathrm{C}\right)$ & 21.7 & 22.5 & 23.6 & NI \\
\hline Thermotolerant coliforms (MPN/100ml) & $7.0 \times 10^{2} \S$ & $4,9 \times 10^{2} \S$ & $1.7 \times 10^{3} \#$ & $<2.0 \times 10^{2}$ \\
\hline Total coliforms (MPN/100ml) & $5,4 \times 10^{4}$ & $5,4 \times 10^{4}$ & $5,4 \times 10^{4}$ & NI \\
\hline
\end{tabular}

NI: not in the resolution. Classification according to the CONAMA Resolution $n^{0} 357$ (except temperature) (Brasil, 2005): Class $1\left(^{*}\right)$, Class 2 (§), Class 3 (\#) and Class $4(\dagger)$.

Therefore, the results revealed the presence of certain heavy metals in the Demetrio stream waters in amounts beyond the standards acceptable, according to the CONAMA Resolution no 357 (Brasil, 2005), and therefore, the waters of the stream were classified as Class 4 in general, based on the $\mathrm{Cu}$ levels and color.

Considering the total analysis of the results, P1 (source), except for its color and Fe concentration, was classified as Class 1 . The degree of color change in all samples (Class 4) manifested an increasing trend from P1 to P3 and was proportional to the increase in turbidity (Class 1 ), which is considered as one of the interference factors for the color criterion. Another important factor for color change was the presence of heavy metals, such as $\mathrm{Fe}$ (Class 3 ) as well as the relative proportionality of variation with color at each sampling point (Figure 2). In addition, Mn in P2 and P3 (Class 3) interfered with the color pattern.

Another factor that correlated $\mathrm{Fe}$ and $\mathrm{Al}$ to natural soil factors was the increasing distributions of the levels found in relation to the distances of the sample points (Figure 3). The analysis of correlation among $\mathrm{Al}, \mathrm{Fe}$, and the distance in which the Demetrio stream traversed was very intense, thus strengthening the hypothesis of the natural increase in concentrations of these two elements. However, $\mathrm{Cu}$ did not present any correlation with natural soil factors,

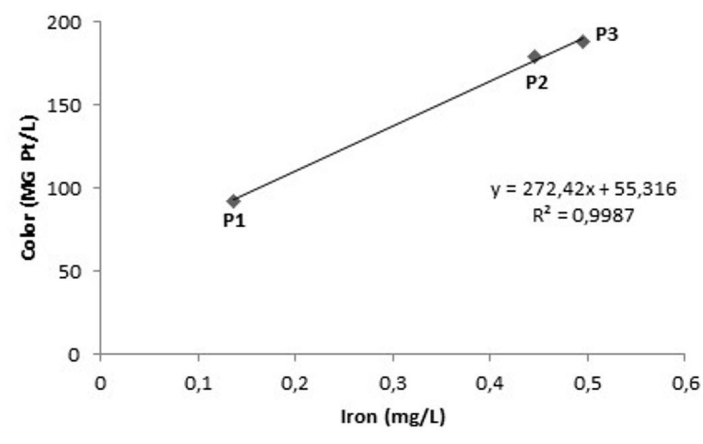

Figure 2. Color and Fe correlation patterns in relation of three water samples of Demétrio stream: point 1 (P1), point 2 (P2) and point 3 (P3).

although it manifested the characteristics of anthropic impacts. It was found that the degree of $\mathrm{Cu}$ concentration decreased from P2 (Class 4) to P3 (Class 3) (Figure 3), thus showing a point of discharge of this component in the path between P1 and P2. Furthermore, the presence of $\mathrm{Mn}$ also reduced the quality of the stream from Class 1 in P1 to Class 3 in P2 and P3 (Figure 3). 
All sampled points had total and thermotolerant coliforms both at near the source (P1) as well as before and after the passage through the area of greater urban density (P2 and P3, respectively). The total coliform value at all sampling points was found to be $5,4 \times 10^{4} / 100 \mathrm{~mL}$ (Table 1). In contrast, for thermotolerant coliforms, a variation between the samples was observed. The highest value $\left(1.7 \times 10^{3} / 100 \mathrm{~mL}\right.$ ) was found in P3 (Class 3$)$, whereas P1 and P2 were classified as Class 2, with $7.0 \times 10^{2} / 100 \mathrm{~mL}$ and $4.9 \times 10^{2} / 100 \mathrm{~mL}$, respectively (Table 1 ).

\subsection{Integrated analysis of physicochemical and microbiological factors}

PCA was used to investigate the relationships between microbiological and physicochemical parameters found

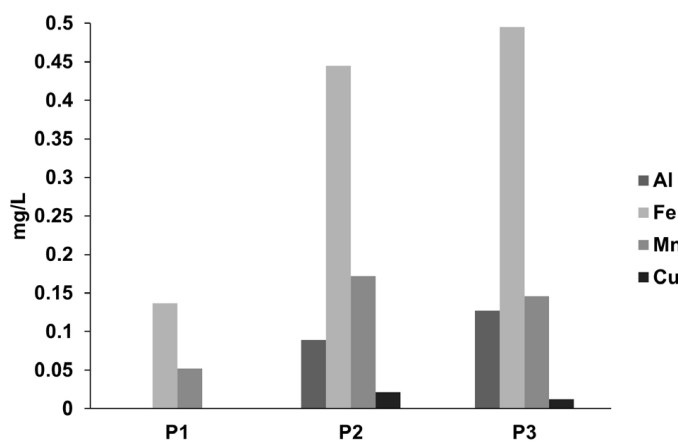

Figure 3. $\mathrm{Al}, \mathrm{Fe}, \mathrm{Mn}$ and $\mathrm{Cu}$ analysis of three water samples of Demétrio stream: point 1 (P1), point 2 (P2) and point 3 (P3). in the sampling points of the Demetrio stream (Table A1 (Annex A) and Figure 4). The two principal components together explained $100 \%$ of the total variability, being that PC1 explained $78.9 \%$ and PC2 explained $21.1 \%$ of the variability. The obtained results allowed to constitute two distinct components of relations through the representation of vectors. Component 1 separated P1 from other sample points and all analyzed parameters. According to Figure 4, it was assumed that P1 had the best water quality. However, P2 and P3 were attributed to the decline in the environmental quality of the Demetrio stream due to the increases in concentrations of all the analyzed elements. In addition, component 2 separated $\mathrm{P} 2$ from $\mathrm{P} 3$ and grouped the presence of coliforms with nitrates.

\subsection{Cytotoxic and genotoxic potential analysis}

The values of germination index (GI) did not differ among the seeds exposed to the Demetrio stream water samples. Considering GI of the negative control group as $100 \%$, the values varied from $86 \%$ to $91 \%$ of seeds germinated (Table 2). The values of mitotic index (MI), micronuclei (MN), nuclear bud (NB), and others chromosomal alterations observed in A. cepa cells are also presented in Table 2.

It was found that the percentages of mitotic cells (metaphase, anaphase, and telophase) did not differ between the groups. When compared to negative control, an increase in micronucleus for $\mathrm{P} 1(\mathrm{P}<0.01)$ and $\mathrm{P} 2(\mathrm{P}<0.01)$, in nuclear buds for $\mathrm{P} 2(\mathrm{P}<0.01)$, and in other chromosomal alteration for $\mathrm{P} 1(\mathrm{P}<0.05)$ and $\mathrm{P} 2(\mathrm{P}<0.01)$ were observed (Table 2). Therefore, although $\mathrm{P} 3$ presented less cell division as compared to others sample points, the phytotoxic (GI)

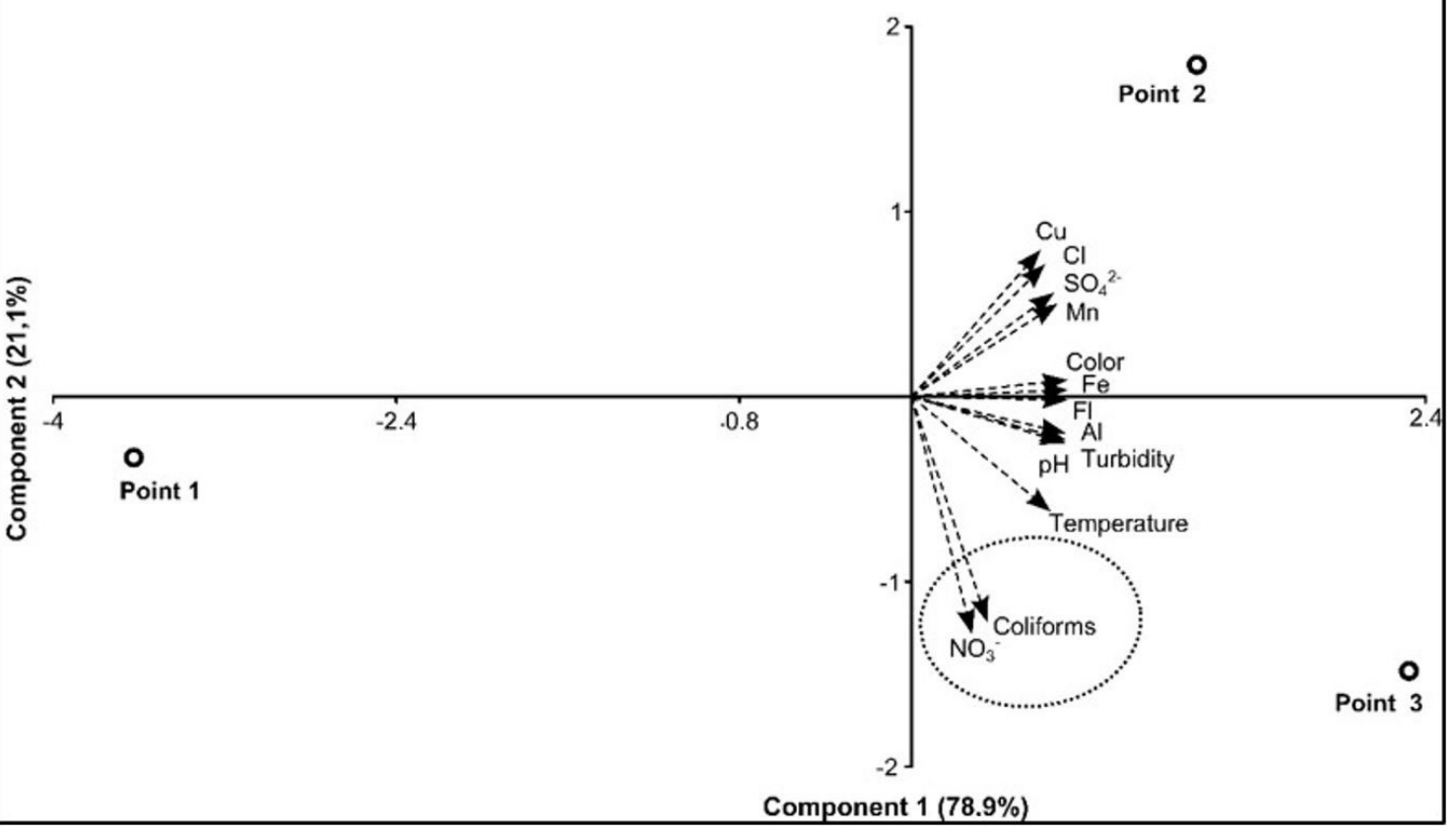

Figure 4. Integrated analysis of physicochemical and microbiological factors (PCA) of three water samples of Demétrio stream: point 1, point 2 and point 3. Component 1, with 78.9\% affinity, separates component 2 with $21.1 \%$ affinity. 
Table 2. Mean and standard deviation of germination index (GI), mitotic index (MI), micronuclei (MN), nuclear bud (NB) and some of others chromosomal alterations observed in meristematic cells of A. cepa exposed to water samples of Demétrio stream: point 1 (P1), point 2 (P2) and point 3 (P3).

\begin{tabular}{cccccc}
\hline Groups & GI (\%) & MI & MN & NB & $\begin{array}{c}\text { Chromosomal } \\
\text { alterations }^{\mathbf{a}}\end{array}$ \\
\hline Negative control $^{\mathrm{b}}$ & 100 & $0.60 \pm 0.40$ & $1.80 \pm 3.49$ & $0.00 \pm 0.00$ & $0.10 \pm 0.32$ \\
P1 & $91.25 \pm 26.52$ & $1.32 \pm 1.04$ & $9.60 \pm 5.89^{* *}$ & $0.50 \pm 0.71$ & $1.50 \pm 1.65^{*}$ \\
P2 & $88.75 \pm 15.91$ & $1.10 \pm 0.62$ & $10.60 \pm 7.75^{* *}$ & $1.60 \pm 1.70^{* *}$ & $1.00 \pm 0.82^{* *}$ \\
P3 & $86.25 \pm 1.77$ & $0.58 \pm 0.46$ & $5.10 \pm 4.23$ & $0.30 \pm 0.67$ & $0.70 \pm 0.95$ \\
Positive controlc $^{\mathrm{c}}$ & $87.50 \pm 3.54$ & $1.36 \pm 1.16$ & $6.70 \pm 5.60$ & $0.70 \pm 1.57$ & $1.40 \pm 1.35$ \\
\hline
\end{tabular}

aSum of interphase, anaphase and telophase with nucleoplasmatic bridge, micronucleus in telophase and anaphase and metaphase with chromosomal loss; 'Distilled water; ' Copper sulfate $(0,0002 \mathrm{~g} / \mathrm{L})$; Significant difference in relation to negative control group ( ${ }^{*} \mathrm{P}<0,05 \mathrm{e}$ $\left.{ }_{* *} \mathrm{P}<0,01\right)$. ANOVA/Kruskal-Wallis test.

and the cytotoxic (MI) effects of the Demetrio stream water samples were not statically revealed. In the case of genotoxic and mutagenic parameters, some sample points manifested difference in relation to negative control.

\section{Discussion}

The Demetrio stream is one of the main affluents of the Gravataí River, which is among the ten most polluted rivers in Brazil (Pessoa, 2017). Our work is the first one to determine the physicochemical, microbiological characteristics with possible cytotoxic and genotoxic changes in this important affluent of the Gravataí River. It should be noted that the results obtained represent a single point in time, and seasonal variations could not be considered in our study.

It is evident that the presence of heavy metals in the Demetrio stream was above acceptable standards according to CONAMA Resolution no 357 (Brasil, 2005). In an earlier study (Rio Grande do Sul, 2012), it was expressed that Class 4 elements were found near the mouth of the Gravataí River. Moreover, Mn and Fe were classified as Class 3, as well as in the report by Bourscheid Engenharia e Meio Ambiente S.A. (2012), whereas other elements remained in Class 1 (Rio Grande do Sul, 2012). It is proved that these metals are associated with agricultural, domestic, or industrial contamination; hence, their dissolved forms tend to present a greater risk to living organisms. Frías-Espericueta et al. (2003) performed a toxicity study for $\mathrm{Cu}, \mathrm{Zn}, \mathrm{Fe}$, and $\mathrm{Mn}$ with shrimp larvae (Litopenaeus vannamel) and concluded that the dissolved metals presented higher toxicity to the organisms because they were absorbed with greater ease in comparison to particulates. Ribeiro et al. (2012) surveyed the pollutants that interfered with the water quality of the São Francisco River (Brazil) and posited that $\mathrm{Fe}, \mathrm{Al}$, and $\mathrm{Mn}$ were related to domestic pollution; $\mathrm{Cu}, \mathrm{Cd}$, and Ni originated from urban-industrial pollution and agricultural use; barium (Ba), $\mathrm{Al}, \mathrm{Fe}, \mathrm{Pb}$, and $\mathrm{Cr}$ with $\mathrm{Zn}$ in suspension were found in industrial areas.

According to the National Health Foundation (FUNASA, 2013), the color pattern classified as Class 4 could be due to Fe and $\mathrm{Mn}$, and the high concentration of Fe could be attributed to the presence of iron, hematite, and goethite in Red-Yellow Alic Argis soil (IBGE, 2002). Rio Grande do
Sul (2012) and Bourscheid Engenharia e Meio Ambiente S.A. (2012) expounded that the color change reduced the quality of the Demetrio stream to Class 4 . The gradual increase in $\mathrm{Al}$ content of $\mathrm{P} 3$ could be associated with the type of soil in which the watercourse was found (Rio Grande do Sul, 2017). The results of PCA analysis corroborate that P2 presented a direct relationship between $\mathrm{Cu}$ and $\mathrm{Mn}$, whereas the increase in concentration between P2 and $\mathrm{P} 3$ was related to the natural conditions of the Demetrio stream: color, $\mathrm{Fe}, \mathrm{Al}$, and $\mathrm{pH}$.

Furthermore, $\mathrm{Cu}$ was found as Class 4 in P2, and according to Benites et al. (2014), Cu is the major agricultural pollutant. Rural properties and silviculture areas were close to the sample points of the Demetrio stream, thus facilitating the Cu contamination of water by agricultural pesticides and fertilizers (Menezes et al., 2009). Sampaio et al. (2013) advocated that industrial discharge could be another reason for the high concentration of $\mathrm{Cu}$. The Economics and Statistics Foundation (FEE, 2012) classified the polluting potentials of industries in the municipalities of State of Rio Grande do Sul (Brazil) in relation to environmental risks and placed the city of Gravataí in the $4^{\text {th }}$ place. This information highlights the possible risks of contamination of the Demetrio stream. According to Benites et al. (2014), Cu could be absorbed by living organisms, and the high concentration could even cause cancer (Barbosa et al., 2010).

The release of organic effluents into water results in the growth of pathogenic microorganisms, which in turn causes numerous diseases (Márquez et al., 1994). According to CONAMA Resolution nº 357 (Brasil, 2005), in water classified as Class 1, the limit of 200 thermotolerant coliforms per $100 \mathrm{~mL}$ should not be exceeded. In sample $\mathrm{P} 1$, it is possible to observe the use of water for recreation, thus even being near the source, it receives a load of thermotolerant coliforms. It was presumed that as P1 was closer to the forming agent, it would be less affected by possible anthropogenic contamination. In sample P2, which precedes the area with greater urban density, water is used for fishing activities. Due to the lack of basic sanitation in most of the population residing in the route between P2 and P3, sample P3 (Class 3) is used for bathing and fishing.

The Demetrio stream runs its widest stretch in the Gravataí city, which provides the highest amount of 
Brazilian sanitation with $53.84 \%$ of the city sewage being collected for treatment (Brasil, 2016). However, due to the increase in urban density and irregular release of sewage, high coliform rates are often found in the Demetrio stream. In a previous study (Rio Grande do Sul, 2012), high levels of total coliforms, phosphorus, and chemical oxygen demand were observed, it could be associated with the lower dilution of domestic effluents from the Gravataí city. Alves et al. (2015) studied the "Canal de Passagem" located in the Vitória city (Espírito Santo, Brazil) and stated that the places most affected with fecal pollution are closer to contamination sources. Oliveira et al. (2012) also confirmed this trend along the Dilúvio stream in Viamão and Porto Alegre (Rio Grande do Sul, Brazil); however, in Lake Guaíba, a reduction in thermotolerant coliform concentration was noticed due to the interference resulting from the variation in water of the Lake. It is important to note that sample P3 of the Demetrio stream was selected at $2.8 \mathrm{~km}$ from the mouth of the Gravataí River in order to avoid any interference from the variation in river water. The level of coliforms found near the source (P1) may be related to the presence of rural residences and properties (nearly 20 meters from the stream) located at higher elevation, about $250 \mathrm{~m}$ above sea level, with its mouth on the Gravatai River, where it is located at an altitude of approximately $5 \mathrm{~m}$ (Rio Grande do Sul, 2012). This altimetric amplitude shows an important characteristic regarding the water's drainage in this basin. Vanzela et al. (2010) expressed that inhabited areas, mainly rural dwellings, tend to increase the thermotolerant coliform indexes in their waters due to the raising of animals near the houses.

Cytogenotoxic study is an important tool to detect changes in living organisms due to water contaminants. Silva and Nascimento (2013) analyzed the cytogenotoxic alterations in $A$. cepa cells exposed to the sample water of Tietê River (São Paulo, Brazil) in order to evaluate the water quality and the risks to biological communities and related these effects to complex interactions of domestic and industrial pollutants released in the river. In our study, the genotoxic and the mutagenic effects were observed in A. cepa cells exposed to water at sample P1 and P2, it can be attributed to the increases in heavy metal concentrations at these sites. Moreover, between these two points, chromosomal instability due to micronucleus, nuclear bud, and other chromosomal alterations was observed. P2 presented the worse water quality as compared to others points due to higher levels of dissolved $\mathrm{Cu}$, dissolved $\mathrm{Fe}$, and Mn, thus it manifested higher DNA damage levels. Maceda et al. (2015) related the genotoxic effect of Cu with the micronucleic formation in fish cells. Arambasic et al. (1995) exposed different organisms, such as Allium cepa L., Lepidium sativum L., and Daphnia magna to $\mathrm{Cu}, \mathrm{Pb}, \mathrm{Zn}$, phenol, and sodium, and $\mathrm{Cu}$ was the most toxic substance. Freshwater fishes, such as Rasbora sumatrana and Poecilia reticulata were exposed to different heavy metals, and it was propounded that $\mathrm{Cu}$ was the most toxic element for both species (Shuhaimi-Othman et al., 2015). Benites et al. (2014) evidenced the changes in Danio rerio cells exposed to the Uruguay River's water with high Cu concentration. No significant alterations were found in GI; however, other studies with Allium cepa presented a root growth reduction due to $\mathrm{Cu}$ exposure. Palacio et al., (2005) evaluated the value of GI in Allium cepa exposed to several heavy metals and identified that $\mathrm{Cu}$ and $\mathrm{Pb}$ significantly reduced the root growth. Fiskesjo (1985) asserted that Cu significantly impeded the growth of Allium cepa seedlings.

In our study, all sample points manifested high Fe concentrations. According to Jadoon and Malik (2017), Fe can increase free radicals' production rates in living organisms, thus causes further DNA damage. Chandra et al. (2005) found that high concentrations of $\mathrm{Fe}, \mathrm{Cr}$, and $\mathrm{Ni}$ in metal waste leachate caused cytogenetic alterations in A. cepa cells. Lasier et al. (2000) investigated the effects of Mn on Ceriodaphnia dubia and Hyalella azteca and concluded that Mn caused chronic toxicity from $3.9 \mathrm{mg} / \mathrm{L}$ and acute toxicity from $6.2 \mathrm{mg} / \mathrm{L}$. Doroftei et al. (2010) characterized the $A$. cepa radicles exposed to $\mathrm{Mn}$ in the presence of disorganized nuclei and cytogenetic damages. In P3, although the concentrations of $\mathrm{Cu}, \mathrm{Al}, \mathrm{Fe}$, and $\mathrm{Mn}$ were above acceptable standards according to CONAMA no 357 (Brasil, 2005), no mutagenic effect was detected. It can be assumed that this complex mixture reduced the rates of cell division and chromosomal damage. Li et al. (2015) identified the progressive MI reduction in Helianthus annuus (sunflower) exposed to Al increase. Marin and Santos (2008) also expressed that Al caused toxicity in plants and reduced the density and the growth of roots. Francisco et al. (2018) noticed a decrease in MI in meristematic cells of A. cepa exposed to Al. Fenech et al. (1999) affirming that DNA damage was dependent on the rate of cell division. P3 manifested low germination and mitotic indexes as compared to samples P1 and P2, thus no significant cytotoxic effect was observed at this P3.

\section{Conclusion}

The monitoring of the Demetrio stream by utilizing various bioindicators is essential for the evaluation of its water quality, considering that this one of the main affluent of the Gravataí River that supplies with drink water the metropolitan region of Porto Alegre (RS, Brazil). The results found in this study demonstrated the low environmental quality of the Demetrio stream according to CONAMA Resolution no 357 (Brasil, 2005), it can be attributed to natural soil toxicity of the region as well as to anthropic actions. Demétrio Stream were classified as Class 4 that is, the water is suitable only for navigation and to landscape harmony, according to their color patterns and high $\mathrm{Cu}$ concentration. Toxic elements, such as $\mathrm{Mn}$ and $\mathrm{Cu}$, were dumped in the stream, thus resulting in a severe degradation in the Demetrio stream's environmental quality. With the use of cytogenotoxic tests performed for the assessment of water quality, the main genotoxic alterations were observed in the water from P2, upstream near the area with the highest urban density, which also exhibited the highest concentration of $\mathrm{Cu}$ in addition to high concentrations of $\mathrm{Fe}$, and $\mathrm{Mn}$; these high metal concentrations might be related to the alterations obtained in the water from P2. 


\section{References}

ALVES, M.M., BARROSO, G.F. and RODRIGUES NETO, R., 2015. Spatial and temporal distribution of thermotolerant coliform in Canal de Passagem (Vitória - ES) - related to physico-chemical parameters and tide. Brazilian Journal of Oceanography, vol. 63, no. 4, pp. 423-428. http://dx.doi.org/10.1590/S1679-87592015090806304.

AMERICAN PUBLIC HEALTH ASSOCIATION - APHA, 2005. Standard methods for the examination of water and wastewater. 21st ed. New York: APHA, 1504 p.

ARAMBASIC, M.B., BJELIC, S. and SUBAKOV, G., 1995. Acute toxicity of heavy metals (copper, lead, zinc), phenol and sodium on Allium cepa L., Lepidium sativum L. and Daphnia magna St.: comparative investigations and the practical applications. Water Research, vol. 29, no. 2, pp. 497-503. http://dx.doi. org/10.1016/0043-1354(94)00178-A.

are PALACIO, S.M., ESPINOZA-QUIÑONES, F.R., GALANTE, R.M., ZENATTI, D.C., SEOLATTO, A.A., LORENZ, E.K., ZACARKIM, C.E., ROSSI, N., RIZZUTTO, M.A. and TABACNIKS, M.H., 2005. Correlation between heavy metal ions (copper, zinc, lead) concentrations and root length of Allium cepa $\mathrm{L}$. in polluted river water. Brazilian Archives of Biology and Technology, vol. 48, no. spe, pp. 191-196. http://dx.doi.org/10.1590/S1516-89132005000400024.

BARBOSA, J.S., CABRAL, T.M., FERREIRA, D.N., AGNEZ-LIMA, L.F. and MEDEIROS, S.R.B., 2010. Genotoxicity assessment in aquatic environment impacted by the presence of heavy metals. Ecotoxicology and Environmental Safety, vol. 73, no. 3, pp. 320-325. http://dx.doi.org/10.1016/j.ecoenv.2009.10.008. PMid:19910047.

BENITES, L.M., DONCATO, K.B., MINHO, T.S. and PERAZZO, G.X 2014. Avaliação do potencial mutagênico de cobre da água do rio Uruguai. Ciência e Natura, vol. 36, no. 2, pp. 107-113. http:// dx.doi.org/10.5902/2179460X13610.

BOURSCHEID ENGENHARIA E MEIO AMBIENTE S.A., 2012 [viewed 17 July 2020]. Processo de planejamento da bacia do Rio Gravataí [online]. Available from: http://www.comitegravatahy.com.br/ index.php/comite-gravatahy-documentos/category/3-plano-debacia?download=3:plano-de-bacia-relatorio-sintese

BRASIL, 2005 [viewed 13 May 2019]. Resolução nº 357, de 17 de março de 2005. Dispõe sobre a classificação dos corpos de água e diretrizes ambientais para o seu enquadramento, bem como estabelece as condições e padrões de lançamento de efluentes, e dá outras providências [online]. Diário Oficial da República Federativa do Brasil, Brasília, 18 mar. Available from: http:// www2.mma.gov.br/port/conama/legiabre.cfm?codlegi=459

BRASIL. Sistema Nacional de Informações sobre Saneamento - SNIS, 2015 [viewed 13 May 2019]. Diagnóstico dos serviços de água e esgotos - 2015 [online]. Available from: http://www.snis.gov. br/diagnostico-agua-e-esgotos/diagnostico-ae-2015

BRASIL. Sistema Nacional de Informações sobre Saneamento SNIS, 2016 [viewed 13 May 2019]. Diagnóstico dos Serviços de Água e Esgotos - 2016 [online]. Available from: http://www. snis.gov.br/diagnostico-agua-e-esgotos/diagnostico-ae-2016

CARITÁ, R. and MARIN-MORALES, M.A., 2008. Induction of chromosome aberrations in the Allium cepa test system caused by the exposure of seeds to industrial effluents contaminated with azo dyes. Chemosphere, vol. 72, no. 5, pp. 722-725. http:// dx.doi.org/10.1016/j.chemosphere.2008.03.056. PMid:18495201.

CARVALHO, I.M., CAVALCANTE, A.A., DANTAS, A.F., PEREIRA, D.L., ROCHA, F.C., OLIVEIRA, F.M. and DA SILVA, J., 2011. Environmental mutagenicity and toxicity caused by sodium metabisulfite in sea shrimp harvesting in Piauí, Brazil. Chemosphere, vol. 82, no. 7, pp. 1056-1061. http://dx.doi.org/10.1016/j. chemosphere.2010.10.042. PMid:21056453.
CARVALHO, J.C.B. and ORSINE, J.V.C., 2011. Contaminação do meio ambiente por fontes diversas e os agravos à saúde da população. Enciclopédia Biosfera, vol. 7, no. 13, pp. 1107-1118.

CHANDRA, S., CHAUHAN, L.K., MURTHY, R.C., SAXENA, P.N., PANDE, P.N. and GUPTA, S.K., 2005. Comparative biomonitoring of leachates from hazardous solid waste of two industries using Allium test. The Science of the Total Environment, vol. 347, no. 1-3, pp. 46-52. http://dx.doi.org/10.1016/j.scitotenv.2005.01.002. PMid: 16084966.

DALZOCHIO, T., RODRIGUES, G.Z.P., PETRY, I.E., GEHLEN, G. and DA SILVA, L.B., 2016. The use of biomarkers to assess the health of aquatic ecosystems in Brazil: a review. International Aquatic Research., vol. 8, no. 4, pp. 283-298. http://dx.doi.org/10.1007/ s40071-016-0147-9.

DOROFTEI, E., ANTOFIE, M.M., SAVA, D. and ARCUS, M., 2010. Cytogenetic effects induced by manganese and lead microelements on germination at Allium cepa. Botanica Serbica, vol. 34, no. 2, pp. 115-121.

EDBERG, S., ALLEN, M. and SMITH, D., 1988. National field evaluation of a defined substrate method for the simultaneous enumeration of total coliforms and Escherichia coli from drinking water: comparison with the standard multiple tube fermentation method. Applied and Environmental Microbiology, vol. 54, no. 6, pp. 1595-1601. http://dx.doi.org/10.1128/AEM.54.6.15951601.1988. PMid:3046490.

FENECH, M., HOLLAND, N., CHANG, W.P., ZEIGER, E. and BONASSI, S., 1999. The Human Micro Nucleus Project: an international collaborative study on the use of the micronucleus: technique for measuring DNA damage in humans. Mutation Research. Fundamental and Molecular Mechanisms of Mutagenesis, vol. 428, no. 1-2, pp. 271-283. http://dx.doi.org/10.1016/S13835742(99)00053-8. PMid:10517999.

FISKESJO, G., 1985. The Allium test as a standard in environmental monitoring. Hereditas, vol. 102, no. 1, pp. 99-112. http://dx.doi. org/10.1111/j.1601-5223.1985.tb00471.x. PMid:3988545.

FISKESJO, G., 1993. The Allium test in wastewater monitoring. Environmental Toxicology and Water Quality, vol. 8, no. 3, pp. 291-298. http://dx.doi.org/10.1002/tox.2530080306.

FRANCISCO, L.F.V., CRISPIM, B.A., VIANA, L.F., NASCIMENTO, H.S., RAPOSO JUNIOR, J.L. and GRISOLIA, A.B., 2018. Cytotoxicity, genotoxicity and mutagenicity of aluminum, manganese and lead in meristematic cells of root Allium cepa. Orbital: the Electronic. Journal of Chemistry, vol. 10, no. 1, pp. 60-65. http:// dx.doi.org/10.17807/orbital.v10i1.1037.

FRÍAS-ESPERICUETA, M.G., VOLTOLINA, D. and OSUNA-LÓPEZ, J.I., 2003. Acute toxicity of copper, zinc, iron, and manganese and of the mixtures copper-zinc and iron-manganese to whiteleg shrimp Litopenaeus vannamei postlarvae. Bulletin of Environmental Contamination and Toxicology, vol. 71, no. 1, pp. 68-74. http://dx.doi.org/10.1007/s00128-003-0132-z. PMid: 12945844.

FUNDAÇÃO DE ECONOMIA E ESTATÍSTICA - FEE, 2012 [viewed 13 May 2019]. Potencial poluidor da indústria no RS: análise dos dados 2002-2009 [online]. Available from: https://www. fee.rs.gov.br/indicadores/indicadores-ambientais/destaques/

FUNDAÇÃO NACIONAL DE SAÚDE - FUNASA, 2013. Manual prático de análise de água. Brasília: FUNASA, $150 \mathrm{p}$.

INSTITUTO BRASILEIRO DE GEOGRAFIA E ESTATISTICA - IBGE, 2002 [viewed 13 May 2019]. Mapa exploratório de Solos do Estado do Rio Grande do Sul [online]. Available from: ftp:// geoftp.ibge.gov.br/informacoes_ambientais/pedologia/mapas/ unidades_da_federacao/rs_pedologia.pdf 
JADOON, S. and MALIK, A., 2017. DNA damage by heavy metals in animals and human beings: an overview. Biochemical Pharmacology, vol. 6, no. 3, pp. 1-8. http://dx.doi. org/10.4172/2167-0501.1000235.

KALIBERDA, F.C., BUSCHINI, M.L.T., PITTNER, E. and MONTEIRO, M.C., 2008. Enteroparasitas presentes no Arroio do Engenho no município de Guarapuava, Paraná. Ambiência, vol. 4, no. 3, pp. 383-395.

LASIER, P.J., WINGER, P.V. and BOGENRIEDER, K.J., 2000. Toxicity of manganese to Ceriodaphnia dubia and Hyalella azteca. Archives of Environmental Contamination and Toxicology, vol. 38, no. 3, pp. 298-304. http://dx.doi.org/10.1007/s002449910039. PMid:10667926.

LEME, D.M. and MARIN-MORALES, M.A., 2008. Chromosome aberration and micronucleus frequencies in Allium cepa cells exposed to petroleum polluted water: a case study. Mutation Research/Genetic Toxicology and Environmental Mutagenesis, vol. 650 , no. 1 , pp. 80-86. http://dx.doi.org/10.1016/j. mrgentox.2007.10.006. PMid:18068420.

LEME, D.M. and MARIN-MORALES, M.A., 2009. Allium cepa test in environmental monitoring: a review on its application. Mutation Research/Reviews in Mutation Research, vol. 682, no. 1, pp. 71-81. http://dx.doi.org/10.1016/j.mrrev.2009.06.002. PMid:19577002.

LI, M., QIN, R., JIANG, W. and LIU, D., 2015. Cytogenetical effects of aluminum on root meristem cells of Helianthus annuus l. Botanical Sciences, vol. 93, no. 1, pp. 15-22. http://dx.doi. org/10.17129/botsci.230.

MACEDA, E.B., GRISOLIA, A.B., VAINI, J.O. and CANDIDO, L.S., 2015. Uso de biomarcadores para monitoramento das águas do Córrego Arara no município de Rio Brilhante, MS, Brasil. Revista Ambiente É Água, vol. 10, no. 1, pp. 117-129. http:// dx.doi.org/10.4136/ambi-agua.1500.

MARIN, A. and SANTOS, D.M.M., 2008. Interação da deficiência hídrica e da toxicidade do alumínio em guandu cultivado em hidroponia. Pesquisa Agropecuária Brasileira, vol. 43, no. 10, pp. 1267-1275. http://dx.doi.org/10.1590/S0100204X2008001000003.

MARQUEZ, A.P.I., DAVILA, C.M.L., KU-PECH, P. and SEGOVIA, P.T., 1994. Calidad sanitaria de los suministros de agua para consumo humano en Campeche. Salud Pública de México, vol. 36, no. 6, pp. 655-661. PMid:7892641.

MATSUMOTO, S.T., MANTOVANI, M.S., MALAGUTTII, M.I.A., DIAS, A.L., FONSECA, I.C. and MARIN-MORALES, M.A., 2006. Genotoxicity and mutagenicity of water contaminated with tannery effluents, as evaluated by the micronucleus test and comet assay using the fish Oreochromis niloticus and chromosomes aberrations in onion roottips. Genetics and Molecular Biology, vol. 29, no. 1, pp. 148-158. http://dx.doi.org/10.1590/S1415-47572006000100028.

MELLO, M.L.S. and VIDAL, B.C., 1978. A reação de Feulgen. Ciência e Cultura, vol. 30, pp. 665-676.

MENEZES, J.M., PRADO, R.B., SILVA JÚNIOR, G.C., MANSUR, K.L. and OLIVEIRA, E.S., 2009. Qualidade da água e sua relação espacial com as fontes de contaminação antrópicas e naturais: bacia hidrográfica do rio São Domingos-RJ. Engenharia Agrícola, vol. 29, no. 4, pp. 687-698. http://dx.doi.org/10.1590/S010069162009000400019.

MERTEN, G.H. and MINELLA, J.P., 2002. Qualidade da água em bacias hidrográficas rurais: um desafio atual para a sobrevivência futura. Agroecologia e Desenvolvimento Rural Sustentável, vol. 3, no. 4, pp. 33-38.
OLIVEIRA, D.V., SILVA, T.C., ZANIN, J.G., NACHTIGALL, G., MEDEIROS, A.W., FRAZZON, A.P.G. and VAN DER SAND, S.T., 2012. Qualidade da água e identificação de bactérias gram-negativas isoladas do Arroio Dilúvio, Porto Alegre, Rio Grande do Sul, Brasil. Evidência, vol. 12, no. 1, pp. 51-62.

PESSOA, M.L., 2017 [viewed 13 May 2019]. O Brasil e o Rio Grande do Sul diante do desafio global da gestão dos recursos hídricos [online]. Available from: http://panoramainternacional.fee.tche. br/article/o-brasil-e-o-rio-grande-do-sul-diante-do-desafioglobal-da-gestao-dos-recursos-hidricos/

QUEVEDO, R.P., BELLOLI, T.F., DE OLIVEIRA, G.G., GUASSELLI, L.A., ETCHELAR, C.B. and BRUBACHER, J.P., 2017. Spatialization of Susceptibility to Flooding in the Demétrio Stream Basin, Gravataí-RS. Revista Brasileira de Cartografia, vol. 69, no. 7, pp. 1371-1386.

RIBEIRO, E.V., MAGALHÃES JUNIOR, A.P., HORN, A.H. and TRINDADE, W.M., 2012. Metais pesados e qualidade da água do Rio São Francisco no segmento entre Três Marias e Pirapora - MG: índice de contaminação. Geonomos, vol. 20, no. 1, pp. 49-63. http://dx.doi.org/10.18285/geonomos.v20i1.27.

RIO GRANDE DO SUL, 2012 [viewed 13 May 2019]. Resolução $n^{0}$ 113/2012. Aprova o enquadramento das águas superficiais da Bacia Hidrográfica do Rio Gravataí [online]. Diário Oficial do Estado, Porto Alegre, 5 nov. Available from: http://www. sema.rs.gov.br/upload/arquivos/201708/22162306-resolucaocrh-113-2012-aprova-enquadramento-das-aguas-superficiaisdo-rio-gravatai-05-11.pdf

RIO GRANDE DO SUL, 2017 [viewed 13 May 2019]. Atlas socioeconômico do Rio Grande do Sul [online]. Available from: http://www.atlassocioeconomico.rs.gov.br/solos

SALOMONI, S.E., ROCHA, O., HERMANY, G. and LOBO, E.A., 2011. Application of water quality biological indices using diatoms as bioindicators in the Gravataí river, RS, Brazil. Brazilian Journal of Biology = Revista Brasileira de Biologia, vol. 71, no. 4, pp. 949959. http://dx.doi.org/10.1590/S1519-69842011000500015.

SAMPAIO, F.G., BOIJINK, C. and RANTIN, F.T., 2013. 0 uso do sulfato de cobre em ecossistemas aquáticos: fatores que afetam sua toxicidade em peixes de água doce. Jaguariúna: Embrapa Meio Ambiente, $101 \mathrm{p}$.

SHUHAIMI-OTHMAN, M., YAKUB, N., RAMLE, N.A. and ABAS, A., 2015. Comparative toxicity of eight metals on freshwater fish. Toxicology and Industrial Health, vol. 31, no. 9, pp. 773-782. http://dx.doi.org/10.1177/0748233712472519. PMid:23302712.

SILVA, C.C. and NASCIMENTO, F.M., 2013. Citogenotoxicidade de amostras de água do Rio Tietê em células meristemáticas radiculares de Allium cepa. Atas de Saúde Ambiental-ASA, vol. 1, no. 1, pp. 26-35.

SPERLING, M.V., 2005. Introdução à qualidade das águas e ao tratamento de esgotos. Belo Horizonte: Departamento de Engenharia Sanitária e Ambiental, Universidade Federal de Minas Gerais, 452 p.

VANZELA, L.S., HERNANDEZ, F.B.T. and FRANCO, R.A.M., 2010. Influência do uso e ocupação do solo nos recursos hídricos do Córrego Três Barras, Marinópolis. Revista Brasileira de Engenharia Agrícola e Ambiental, vol. 14, no. 1, pp. 55-64. http://dx.doi. org/10.1590/S1415-43662010000100008.

VOLPI, J.C. and JUNGBLUT, M., 1994. Adequação do uso agrícola do solo da bacia do rio Gravataí/RS. Porto Alegre: CPRM/METROPLAN, 22 p. Série Cartas Temáticas, vol. 4. 


\section{Annex A. Principal Component Analysis (PCA).}

Table A1. Eigenvectors of principal component analysis (PCA) using microbiological and physicochemical parameters in the sampling points of the Demetrio stream.

\begin{tabular}{ccc}
\hline Variable & PC1 & PC2 \\
\hline $\mathrm{Al}$ & 0.3112 & -0.09333 \\
$\mathrm{Cl}$ & 0.2717 & 0.2958 \\
$\mathrm{Cu}$ & 0.2219 & 0.4143 \\
$\mathrm{Fe}$ & 0.3152 & 0.01288 \\
$\mathrm{Fl}$ & 0.3152 & -0.01035 \\
$\mathrm{Mn}$ & 0.2952 & 0.2048 \\
$\mathrm{NO}_{3}{ }^{-}$ & 0.1232 & -0.5369 \\
$\mathrm{SO}_{4}^{2-}$ & 0.2897 & 0.2301 \\
Turbidity & 0.3106 & -0.09995 \\
Color $^{2-}$ & 0.3147 & 0.03424 \\
pH & 0.3101 & -0.1056 \\
Temperature & 0.2821 & -0.2606 \\
Coliforms & 0.1544 & -0.5085 \\
\hline
\end{tabular}

PC1: Principal Component 1; PC2: Principal Component 2. 